GHÂNCARAN: JURNAL
PENDIDIKAN BAHASA DAN
SASTRA INDONESIA
$\begin{gathered}\text { http://ejournal.iainmadura.ac.id/ghancaran } \\ \text { E-ISSN : 2715-9132 ; P-ISSN: 2714-8955 } \\ \text { DOI 10.19105/ghancaran.v2i1.3193 }\end{gathered}$

\title{
TELAAH TINGKAT KESULITAN TEKS EKSPOSISI DALAM BUKU SISWA BAHASA INDONESIA: EKSPRESI DIRI DAN AKADEMIK UNTUK SMA/SMK KELAS X KURIKULUM 2013
}

\author{
Dian Risdiawati* \\ *Tadris Bahasa Indonesia, IAIN Tulungagung \\ Alamat surel: dnrisdi9@gmail.com
}

\begin{tabular}{ll}
\hline \hline & Abstract \\
\hline Keywords: & The purpose of this study is to describe the level of difficulty based \\
The level of & on the complexity meaning of the exposition text in the student's \\
difficulty; & book Bahasa Indonesia: Ekspresi Diri dan Akademik untuk \\
Complexity & SMA/SMK kelas X kurikulum 2013. The data is exposition text \\
meaning; & sourced in the textbooks. Data were analyzed with a qualitative \\
Exposition & descriptive design. The results of the analysis complexity meaning \\
text. & of exposition text on 2013 Curriculum teaching materials are affix \\
& more dominant than other. The most influential words that appear \\
& are the words that get affixes me-kan. The words used in the \\
exposition text refer to the theme of the text. The exposition text is \\
in accordance with the level of student thinking.
\end{tabular}

\begin{tabular}{|c|c|}
\hline \multirow[b]{2}{*}{$\begin{array}{l}\text { Kata Kunci: } \\
\text { Tingkat kesulitan; } \\
\text { Kompleksitas } \\
\text { makna; } \\
\text { Teks eksposisi. }\end{array}$} & Abstrak: \\
\hline & $\begin{array}{l}\text { Tujuan penelitian ini untuk mendeskripsikan tingkat kesulitan } \\
\text { berdasarkan kompleksitas makna teks eksposisi yang terdapat } \\
\text { pada buku siswa Bahasa Indonesia: Ekspresi Diri dan Akademik } \\
\text { untuk SMA/SMK kelas X kurikulum 2013. Data berupa teks } \\
\text { eksposisi yang bersumber pada buku teks. Data dianalisis dengan } \\
\text { desain deskriptif kualitatif. Hasil analisis kompleksitas makna pada } \\
\text { teks eksposisi kelas X pada bahan ajar Kurikulum } 2013 \text { lebih } \\
\text { dominan pada bentuk pengimbuhan. Kata berimbuhan yang paling } \\
\text { banyak muncul adalah kata yang mendapatkan imbuhan me-kan. } \\
\text { Kata yang digunakan di dalam teks eskposisi mengarah ke tema } \\
\text { teks. Teks eksposisi tersebut sesuai dengan tingkat berpikir siswa. }\end{array}$ \\
\hline Terkirim & Diterima: 22 Juli 2020 \\
\hline & $\begin{array}{c}\text { OGhâncaran: Jurnal Pendidikan Bahasa dan Sastra Indonesia } \\
\text { Tadris Bahasa Indonesia } \\
\text { Institut Agama Islam Negeri Madura, Indonesia }\end{array}$ \\
\hline
\end{tabular}

\section{PENDAHULUAN}

Saat ini, dunia pendidikan di Indonesia tengah menerapkan kurikulum terbaru yaitu kurikulum 2013. Mata pelajaran Bahasa Indonesia pun tidak luput dari aturan kurikulum baru tersebut. Dalam penerapannya, Kurikulum 2013 sangat berbeda dibandingkan dengan kurikulum sebelumnya yaitu Kurikulum Tingkat Satuan Pendidikan. Berdasarkan Kurikulum 2013, mata pelajaran Bahasa Indonesia dibuat berbasis teks dan dibentuk ruh bahwa bahasa Indonesia tidak hanya sebagai sarana komunikasi, tetapi juga sebagai sarana pengembangan kemampuan berpikir dan pengembangan karakter. 
Dalam mata pelajaran Bahasa Indonesia Kurikulum 2013, teks menjadi unsur penting. Hal ini disebabkan pembelajaran berbasis teks lebih menekankan pada siswa untuk memahami berbagai jenis teks dan menuntut siswa untuk mahir menulis.Selain itu, pembelajaran berbasis teks ini sejalan dengan langkah dalam pendekatan ilmiah (scientific aproach). Dengan demikian, pembelajaran bahasa mendukung capaian kompetensi integratif dari pengetahuan, keterampilan, dan sikap. Kemudian, dengan pembelajaran berbasis teks ini, peran pembelajaran bahasa menjadi lintas kurikulum dengan pengertian pembelajaran bahasa menjadi penghela ilmu pengetahuan.

Berbagai ragam teks disajikan dalam buku siswa mata pelajaran Bahasa Indonesia. Pada jenjang SMA/SMK saja terdapat 22 jenis teks, belum lagi pada jejang SMP dan SD. Menurut (Priyatni, 2014), teks dapat dikelompokkan menjadi dua kategori besar (genre), yaitu genre sastra dan genre faktual. Genre faktual merupakan jenis teks yang dibuat berdasarkan kejadian, peristiwa, atau keadaan nyata yang berada di sekitar lingkungan hidup. Sedangkan genre sastra merupakan jenis teks yang dibuat berdasarkan imajinasi, bukan pada kenyataan yang sesungguhnya. Contoh teks yang termasuk dalam genre faktual meliputi teks laporan, deskripsi, prosedur, eksplanasi, eksposisi, dan diskusi. Sedangkan contoh teks yang termasuk dalam genre sastra meliputi anekdot, naratif, dan eksemplum.

Diambil contoh pada jenjang SMA/SMK kelas $X$ teks yang disajikan berupa teks laporan hasil observasi, teks eksposisi, teks anekdot, teks hikayat, teks negosiasi, teks debat, teks biografi, dan puisi (Kebudayaan, 2014). Berdasarkan sajian tersebut terlihat bahwa teks yang mendominasi adalah teks faktual. Tentu saja, teks yang terdapat di tiap jenjang memiliki perbedaan, terutama yang paling terlihat adalah perbedaan tingkat kesulitan dalam pemahaman teks. Semakin tinggi jenjang pendidikan, teks yang disajikan di buku akan lebih sulit. Hal tersebut disebabkan oleh pengaruh tingkat pengetahuan siswa tiap jenjang.

Kriteria kualifikasi kemampuan siswa yang berbeda-beda, berdampak pada pemilihan teks yang disajikan dalam materi pembelajaran. Tidak mungkin teks eksposisi disajikan untuk jenjang SD misalnya, karena memang tidak sesuai dengan tingkat pengetahuan anak SD. Yang jelas anak-anak akan kesulitan dalam memahami bahasa dan ide-ide yang terdapat dalam teks. Paling cocok, teks eksposisi disajikan untuk siswa jenjang SMA/SMK karena dirasa siswa SMA/SMK sudah memiliki pengetahuan dan nalar yang cukup untuk mempelajari dan mengembangkan teks eksposisi.

Dari paparan di atas terlihat bahwa terdapat perbedaan tingkat kesulitan dalam memahami teks. Dalam hal ini, tingkat kesulitan teks tersebut dapat dipengaruhi oleh kompleksitas makna. Bentuk bahasa yang digunakan dan makna yang timbul sangat memengaruhi siswa dalam memahami suatu teks. Sehingga, pemilihan teks untuk disajikan dalam buku siswa harus benar-benar dipilih dan ditelaah sesuai dengan tingkat pengetahuan siswa atau tidak (Taylor, 1990).

Pada pembahasan ini akan diulas secara sederhana mengenai tingkat kesulitan teks berdasarkan kompleksitas makna yang terdapat pada salah satu teks faktual yaitu teks eksposisi dalam buku siswa kelas X SMA/SMK. Teks eksposisi dipilih karena dirasa teks eksposisi mempunyai stuktur teks yang kompleks. Sehingga, terbentuklah tujuan dari penelitian ini yaitu untuk mendeskripsikan tingkat kesulitan teks dilihat dari kompleksitas makna teks eksposisi yang terdapat pada buku siswa Bahasa Indonesia: Ekspresi Diri dan Akademik untuk SMA/SMK kelas X kurikulum 2013 edisi revisi.

\section{Teks Eksposisi}

Teks eksposisi adalah karangan yang memaparkan, menjelaskan, menerangkan, dan menguraikan tentang sesuatu hal dengan penyampaian informasi yang sejelasjelasnya. Menurut (Priyatni, 2014) teks eksposisi adalah teks yang digunakan untuk 
meyakinkan pembaca terhadap opini yang dikemukakan dengan sejumlah argumen pendukung. Struktur teks eksposisi terdiri atas tiga bagian yaitu pernyataan pendapat (tesis), pendapat (mendukung atau menolak), dan penegasan ulang pendapat.

Pernyataan pendapat berisikan pendapat atau prediksi dari penulis berdasarkan sebuah fakta. Pernyataan pendapat, pada bagian ini, masih diuraikan secara umum. Kemudian, pada bagian kedua yaitu pendapat yang berisikan fakta-fakta yang mendukung pendapat di bagian awal. Lalu, bagian terakhir berupa penguatan kembali atas pendapat yang telah ditunjang oleh fakta-fakta dalam bagian pendapat. Pada bagian ini pula bisa dicantumkan hal-hal yang perlu diperhatikan atau dilakukan supaya pendapat atau prediksi dari penulis dapat terbukti. Jadi, dapat dikatakan bahwa struktur teks eksposisi memiliki kesinambungan secara berurutan.

\section{Kompleksitas Makna}

Kompleksitas makna dapat diartikan sebagai kelengkapan makna dari kata/frasa/klausa/kalimat/teks. Makna adalah arti atau maksud yang tersimpul dari suatu kata. Makna dengan bendanya sangat bertautan dan saling menyatu. Jika suatu kata tidak bisa dihubungkan dengan bendanya, peristiwa, atau keadaan tertentu maka tidak bisa diperoleh makna dari kata itu (Tjiptadi, 1984). Kompleksitas makna dapat diketahui diantaranya melalui bentuk bahasa dan makna bahasa. Semakin tinggi tingkat kompleksitas makna di dalam teks, semakin sulit seseorang (siswa) untuk memahami teks tersebut.

Menurut (Chaer, 2008), makna dapat dibedakan berdasarkan ketepatan maknanya, yaitu makna umum (superordinat) dan makna khusus (subordinat). Hubungan makna superordinat dan subordinat mempengaruhi tingkat kompleksitas makna dalam teks. Kata yang menjadi superordinat terletak di kalimat utama sedangkan subordinat terletak di kalimat penjelas. Superordinat bukan hanya kata tetapi juga kalimat yang terdapat di dalam teks. Semakin mudah ditemukan superordinat kalimat di dalam teks semakin mudah siswa (pembaca) memahami teks tersebut.

Proses morfologis juga sangat menentukan sulit tidaknya pembaca, dalam hal ini adalah siswa, untuk dapat memahami sebuah teks. Proses morfologis merupakan proses pembentukan kata (Alwi, 2000). Proses morfologis di dalam bahasa Indonesia terdiri atas tiga macam, yaitu afiksasi, reduplikasi, dan komposisi (Samsuri, 1985). Afiksasi atau lebih dikenal pengimbuhan merupakan pembentukan kata dengan menambahkan morfem afiks pada bentuk kata dasar. Afiksasi dibagi menjadi empat bagian yaitu imbuhan awalan (prefiks), imbuhan tengah (infiks), imbuhan akhir (sufiks), imbuhan awal akhir (konfiks atau simulfiks). Reduplikasi (pengulangan) merupakan pembentukan kata dengan mengulang bentuk dasar. Komposisi (pemajemukan) adalah pembentukan kata dengan menggabungkan dua atau lebih bentuk dasar. Semakin banyak pembentukan kata di dalam teks semakin sulit atau lama pembaca untuk memahami teks tersebut (Masnur, 2008).

\section{METODE}

Penelitian ini merupakan jenis penelitian deskriptif kualitatif. Data penelitian ini adalah teks eksposisi dalam Buku Siswa Bahasa Indonesia: Ekspresi Diri dan Akademik untuk SMA/SMK Kelas X Kurikulum 2013 edisi revisi. Sumber data penelitian ini adalah Buku Siswa Bahasa Indonesia: Ekspresi Diri dan Akademik untuk SMA/SMK Kelas X Kurikulum 2013 edisi revisi. Instrumen penelitian ini adalah peneliti sendiri yang secara langsung terlibat dalam kegiatan perencana, pengumpul data, penganalisisan data, dan pelaporan hasil penelitian. Selain peneliti sebagai instrumen, peneliti menggunakan alat bantu berupa deskriptor karakteristik teks eksposisi.

Data yang telah terkumpul, selanjutnya dianalisis dengan menggunakan teknik analisis data penelitian kualitatif yaitu kegiatan reduksi data, penyajian data, dan 
penarikan kesimpulan. Kegiatan yang dilakukan pada tahap reduksi data meliputi identifikasi data, klasifikasi data, dan kodifikasi data. Identifikasi data penelitian ini berupa penggunaan pengimbuhan (afiksasi), pemajemukan (komposisi), reduplikasi, kata umum (superordinat), dan makna khusus (subordinat). Selanjutnya, data yang diperoleh dari identifikasi itu diklasifikasi berdasarkan jenisnya dan dilakukan pemaknaan berdasarkan kata yang diidentifikasi. Hasil analisis kemudian dikodifikasi sesuai dengan klasifikasinya.

Penyajian data dalam penelitian ini bertujuan untuk memperoleh kesimpulan tingkat kesulitan berdasarkan kompleksitas makna teks eksposisi yang digunakan dalam Buku Siswa Bahasa Indonesia: Ekspresi Diri dan Akademik untuk SMA/SMK Kelas X Kurikulum 2013 edisi revisi. Tahap terakhir dalam analisis data penelitian ini adalah penarikan kesimpulan. Penarikan kesimpulan dalam penelitian ini adalah mengecek kesesuaian dari hasil analisis data dan membuat jaring semantik berdasarkan tema pada teks ekposisi yang disajikan.

\section{HASIL}

Dalam buku siswa Bahasa Indonesia: Ekspresi Diri dan Akademik untuk SMA/SMK Kelas X Kurikulum 2013 edisi revisi ditemukan teks eksposisi dengan judul Untung Rugi Perdagangan Bebas (Priyatni \& Harsiati, 2013). Berdasarkan teks tersebut diperoleh hasil sebagai berikut.

Pertama, proses morfologis pengimbuhan (afiksasi). Dalam teks eksposisi Untung Rugi Perdagangan Bebas pada buku siswa Bahasa Indonesia: Ekspresi Diri dan Akademik untuk SMA/SMK Kelas X Kurikulum 2013 edisi revisi terdapat pengimbuhan (afiksasi) yang menggunakan imbuhan asing yaitu kata proteksionisme. Kata proteksionisme berasal dari kata proteksi yang mendapat imbuhan akhiran -isme. Apabila siswa tidak mengatahui fungsi imbuhan tersebut, siswa akan sulit memahami teks. Fungsi imbuhan -isme adalah paham dari bentuk kata dasar. Jika dikaitkan dengan konteks teks eskposisi Untung Rugi Perdagangan Bebas, maka kata proteksionisme memiliki arti yaitu sebuah paham kondisi ekonomi di negera Indonesia harus dilindungi dari persaingan luar negeri. Selain itu, ditemukan kata pengimbuhan pada teks eksposisi Untung Rugi Perdagangan Bebas yang disajikan dalam tabel berikut.

\begin{tabular}{|l|l|}
\hline \multicolumn{1}{|c|}{ Kata Pengimbuhan } & \multicolumn{1}{c|}{ Kata Dasar } \\
\hline Berimbang & Imbang \\
\hline Berkisar & Kisar \\
\hline Berperan & Peran \\
\hline Bersangkutan & Sangkut \\
\hline Beruntung & Untung \\
\hline Dibatasi & Batas \\
\hline Dicap & Cap \\
\hline Diharapkan & Harap \\
\hline Dipastikan & Pasti \\
\hline Diperoleh & Oleh \\
\hline Diterapkan & Terap \\
\hline Diusung & Usung \\
\hline Hubungan & Hubung \\
\hline Kebijakan & Bijak \\
\hline Kenaikan & Naik \\
\hline Kesejahteraan & Sejahtera \\
\hline Keunggulan & Unggul \\
\hline Membandingkan & Banding \\
\hline Membuat & Buat \\
\hline Memerlukan & Perlu \\
\hline
\end{tabular}




\begin{tabular}{|l|l|}
\hline Memiliki & Milik \\
\hline Memproduksi & Produksi \\
\hline Menciptakan & Cipta \\
\hline Mendapatkan & Dapat \\
\hline Menekankan & Tekan \\
\hline Mengenai & Kena \\
\hline Menguntungkan & Untung \\
\hline Meningkat & Tingkat \\
\hline Meningkatkan & Tingkat \\
\hline Merugi & Rugi \\
\hline Merugikan & Rugi \\
\hline Pakaian & Pakai \\
\hline Pendapatan & Dapat \\
\hline Pendukung & Dukung \\
\hline Peneliti & Teliti \\
\hline Penggunaan & Guna \\
\hline Penjelasan & Jelas \\
\hline Perdagangan & Dagang \\
\hline Perolehan & Oleh \\
\hline Pertimbangkan & Timbang \\
\hline Pertukaran & Tukar \\
\hline Temukan & Temu \\
\hline Terbukti & Bukti \\
\hline Tersedia & Sedia \\
\hline Terukur & Ukur \\
\hline
\end{tabular}

Tabel 1. Daftar Kata Pengimbuhan dari Teks Eksposisi Untung Rugi Perdagangan Bebas

Berdasarkan data kata pengimbuhan di atas, teks eksposisi Untung Rugi Perdagangan Bebas lebih banyak menggunakan kata imbuhan me-kan. Fungsi imbuhan me-kan tersebut adalah untuk menjadikan kata dasar berubah menjadi jenis kata kerja.

Kedua, dilihat dari proses morfologis pemajemukan (komposisi). Dalam teks eksposisi Untung Rugi Perdagangan Bebas ditemukan kata yang mengalami proses pemajemukan yaitu kata sumber daya, antarnegara, anti dumping, neoliberalis, probarang impor, dan pro-asing. Kata majemuk yang digunakan di dalam teks terdapat kata majemuk yang terpisah dan kata majemuk yang ditulis serangkai. Kata majemuk tidak diartikan secara per bagian kata, tapi diartikan keseluruhan kata. Berikut disajikan data kata majemuk yang ditemukan dalam teks beserta maknanya.

\begin{tabular}{|l|l|}
\hline \multicolumn{1}{|c|}{ Kata Majemuk } & \multicolumn{1}{c|}{ Makna } \\
\hline Sumber daya & $\begin{array}{l}\text { faktor produksi terdiri atas } \\
\text { tanah, tenaga kerja, dan modal } \\
\text { yang dipakai dalam kegiatan } \\
\text { ekonomi untuk menghasilkan } \\
\text { barang jasa. }\end{array}$ \\
\hline Antarnegara & $\begin{array}{l}\text { antara negara yg terdapat dl } \\
\text { lingkungan tertentu, antara } \\
\text { beberapa negara. }\end{array}$ \\
\hline Anti dumping & $\begin{array}{l}\text { menentang sistem penjualan } \\
\text { barang di pasaran luar negeri } \\
\text { dalam jumlah banyak dengan } \\
\text { harga yang rendah sekali. }\end{array}$ \\
\hline Neoliberalis & aliran politik ekonomi. \\
\hline Pro-barang impor & $\begin{array}{l}\text { mendukung untuk mengimpor } \\
\text { barang. }\end{array}$ \\
\hline Pro-asing & $\begin{array}{l}\text { mendukung kegiatan } \\
\text { perekonomian yang } \\
\text { menguntungkan negara lain. }\end{array}$ \\
\hline
\end{tabular}


Tabel 2. Daftar Kata Majemuk dari Teks Eksposisi Untung Rugi Perdagangan Bebas

Kata majemuk yang terdapat pada teks eksposisi Untung Rugi Perdagangan Bebas berhubungan dengan konteks teks yaitu pada tema. Ditemukan bahwa tema dari teks eksposisi tersebut adalah perekonomian.

Ketiga, dilihat dari proses morfologis reduplikasi (pengulangan). Pada teks eksposisi Untung Rugi Perdagangan Bebas ini, hanya muncul dua kata pengulangan yaitu kata rata-rata dan berhati-hati. Kata rata-rata termasuk jenis pengulangan seluruh sedangkan kata ulang berhati-hati termasuk kata ulang sebagian. Berikut disajikan data kata pengulangan beserta kata dasar dan maknanya.

\begin{tabular}{|l|l|}
\hline \multicolumn{1}{|c|}{ Kata Ulang } & \multicolumn{1}{c|}{ Kata Dasar } \\
\hline $\begin{array}{l}\text { Rata-rata (sama banyak di } \\
\text { seluruh tempat) }\end{array}$ & $\begin{array}{l}\text { Rata (mempunyai permukaan } \\
\text { yg sama tinggi dan/atau sama } \\
\text { rendah) }\end{array}$ \\
\hline $\begin{array}{l}\text { Berhati-hati (tindakan } \\
\text { yang sangat cermat dan } \\
\text { tidak buru-buru) }\end{array}$ & $\begin{array}{l}\text { Hati (organ badan yg berwarna } \\
\text { kemerah-merahan di bagian } \\
\text { kanan atas rongga perut) }\end{array}$ \\
\hline
\end{tabular}

Tabel 3. Daftar Kata Reduplikasi dari Teks Eksposisi Untung Rugi Perdagangan Bebas

Keempat, kata umum (superordinat) dan makna khusus (subordinat). Hubungan makna superordinat (kata umum) dan subordinat (kata khusus) memudahkan siswa untuk menghubungkan antarkalimat di dalam teks. Superordinat-subordinat membantu siswa untuk menebak kalimat penjelas pada teks. Berikut superordinat-subordinat yang ditemukan dalam teks eksposisi Untung Rugi Perdagangan Bebas.

\begin{tabular}{|l|l|}
\hline \multicolumn{1}{|c|}{ Superordinat } & \multicolumn{1}{c|}{ Subordinat } \\
\hline Negara & Indonesia \\
& Portugal \\
& Cina \\
& Inggris \\
\hline Ekonomi & Perdagangan \\
& Pasar \\
& Keuntungan \\
& Kerugian \\
& Laba \\
& Komoditas \\
\hline Perdagangan & Perdagangan bebas \\
& Perdagangan internasional \\
\hline
\end{tabular}

Tabel 4. Daftar Superordinat-Subordinat dari Teks Eksposisi Untung Rugi Perdagangan Bebas

\section{PEMBAHASAN}

Ciri khas dari materi mata pelajaran Bahasa Indonesia pada Kurikulum 2013 adalah teks atau dikenal dengan istilah kurikulum berbasis teks. Unsur teks menjadi peran utama dalam mengajarkan bahasa kepada siswa. Teks yang digunakan di dalam buku siswa harus benar-benar memudahkan siswa dalam belajar. Teks harus sesuai dengan proses perkembangan siswa sehingga teks yang dipelajari mudah dipahami oleh siswa.

Salah satu teks yang diajarkan dalam buku siswa mata pelajaran Bahasa Indonesia adalah teks eksposisi. Karena teks eksposisi mempunyai struktur yang kompleks, tentu saja teks eksposisi diajarkan pada tingkat SMA/SMK. Salah satu teks eksposisi yang terdapat dalam buku siswa Bahasa Indonesia: Ekspresi Diri dan 
Akademik untuk SMA/SMK Kelas X Kurikulum 2013 edisi revisi berjudul Untung Rugi Perdagangan Bebas.

Hasil analisis teks eksposisi Untung Rugi Perdagangan Bebas menunjukkan bahwa kata yang digunakan di dalam teks mengarah ke tema teks. Tema teks adalah perekonomian. Apabila dibuatkan jaring semantik, perekonomian menjadi unsur penting untuk memahami isi teks. Berikut jaring semantik teks eksposisi Untung Rugi Perdagangan Bebas.

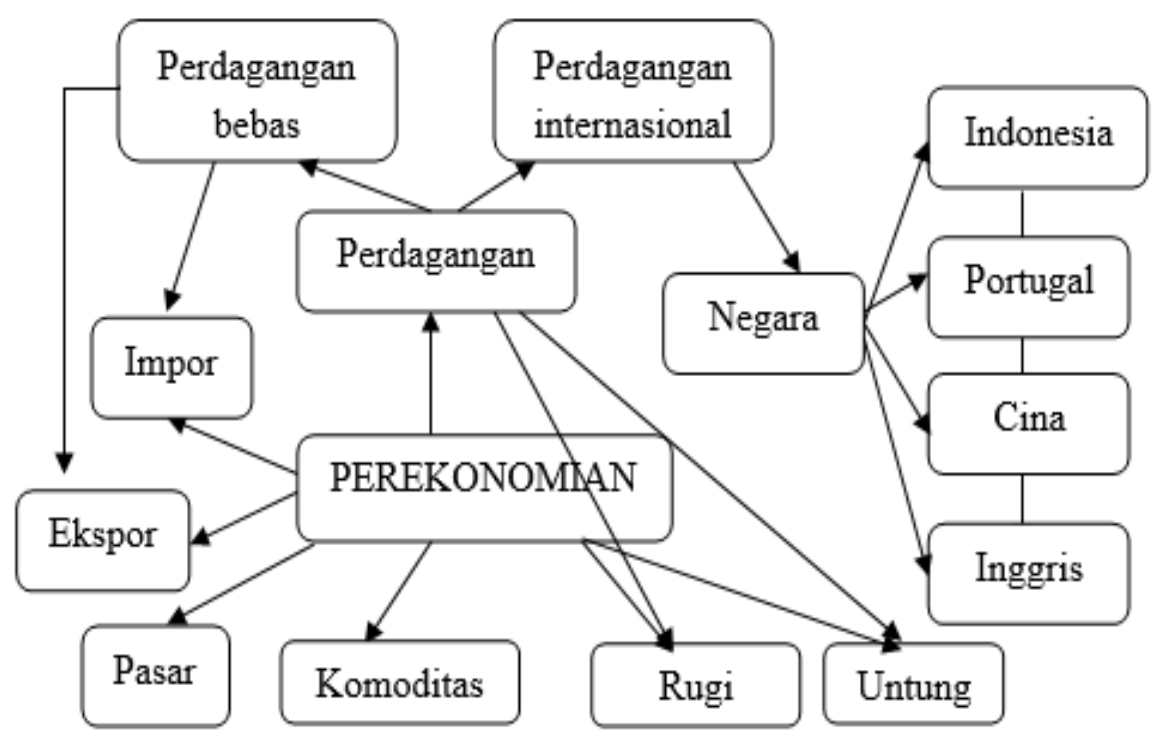

\section{Gambar 1. Jaring Semantik Teks Eksposisi Untung Rugi Perdagangan Bebas}

Jaring semantik atau yang disebut juga sebagai pemetaan makna, merupakan representasi mental unsur-unsur pembangun teks yang digambarkan dalam bentuk peta semantik yang berhubungan antara satu konsep dengan konsep yang lain (Pappas et al., 1995). Pemetaan makna (jaring semantik) tersebut dapat digambarkan berupa skema atau hierarki kata, frasa, dan kalimat yang berfungsi sebagai deskriptor konsep yang ada pada teks dan diorganisasikan berdasarkan prioritas informasi, artinya terdapat tingkatan informasi yang disajikan dalam teks. Tingkatan informasi tersebut dapat dimulai dari tingkat umum ke khusus atau khusus ke umum (superordinat ke subordinat atau subordinat ke superordinat).

Menurut (Kegl, 1989) untuk mengetahui segala sesuatu tentang kosakata yang terkait, tidak cukup untuk membuat individu memahami dan menggunakan makna kosakata dengan kata yang tepat. Oleh karena itu, pengetahuan siswa harus dilengkapi dan dibatasi oleh pengetahuan linguistik untuk menghasilkan pemahaman yang sesuai dengan pengetahuan kata. Pengetahuan linguistik ini mencakup proses-proses morfologis dan fungsi-fungsi morf yang terbentuk. Seperti halnya dalam teks eksposisi Untung Rugi Perdagangan Bebas banyak ditemukan imbuhan me-kan yang fungsinya untuk menjadikan kata dasar berubah menjadi jenis kata kerja.

Hasil analisis juga menunjukkan adanya penggunaan kosakata tunggal maupun majemuk yang terhubung dengan jaring semantik. Pengetahuan siswa secara otomatis akan menghubungan kosakata-kosakata tersebut ke dalam pemetaan makna. (Sinatra et al., 1986) menyatakan bahwa pemetaan makna dapat membantu siswa merepresentasikan secara visual bagaimana kata-kata dan konsep melalui jaringan pengetahuan yang terorganisir. Dengan mengetahui berbagai hubungan sebuah kata di dalam teks akan membantu siswa dalam memahami arti penuh dan membantu mengingat bentuk kata atau maknanya dalam konteks yang tepat (Meier, 2007). 
Pemahaman siswa terhadap teks juga didukung dengan struktur teks eksposisi yang ada. Adanya pernyataan pendapat (tesis), pendapat (mendukung atau menolak), dan penegasan ulang pendapat membuat kosakata dan ide pokok akan berkesinambungan dan berulang. Dari struktur teks tersebut, secara tidak langsung terbentuk peta semantik yang membuat teks eksposisi mudah untuk dipahami oleh siswa secara utuh.

Berdasarkan hasil telaah teks secara keseluruhan, kompleksitas makna dari teks eksposisi Untung Rugi Perdagangan Bebas dapat dikatakan masih sesuai dengan tingkat kesulitan atau tingkat berfikir siswa SMA/SMK. Hal ini buktikan dengan penggunaan bentuk kata yang hanya sedikit menggunakan imbuhan asing dan hanya menggunakan imbuhan lazim digunakan seperti me-kan. Kemudian, kosakata yang digunakan sudah membentuk makna yang saling terhubung. Hal ini dibuktikan dengan adanya hubungan subordinat dan superordinat. Jika dilihat dari jaring semantik yang terbentuk baik jaring semantik kosakata maupun jaring semantik ide yang tersusun dalam struktur teks, dengan mudah ditemukan subordinat-superordinat oleh siswa/pembaca. Sehingga, siswa akan dengan mudah memahami teks eksposisi tersebut.

\section{SIMPULAN}

Dalam buku siswa Bahasa Indonesia: Ekspresi Diri dan Akademik untuk SMA/SMK Kelas X Kurikulum 2013 edisi revisi ditemukan teks eksposisi dengan judul Untung Rugi Perdagangan Bebas. Setelah ditelaah, dalam teks tersebut terdapat kosakata yang mengalami proses morfologis pengimbuhan, pemajemukan, dan pengulangan. Ditemukan sebanyak 45 kata yang mendapat pengimbuhan, 7 kata majemuk, dan 2 kata pengulangan. Selain itu, terdapat 3 kata superordinat yang membantu untuk membentuk jaring makna dalam teks. Dalam teks eksposisi Untung Rugi Perdagangan Bebas, penggunaan bentuk kata hanya sedikit menggunakan imbuhan asing dan hanya menggunakan imbuhan lazim digunakan oleh siswa. Kosakata yang digunakanpun sudah membentuk makna yang saling terhubung. Dilihat dari jaring semantik yang terbentuk baik jaring semantik kosakata maupun jaring semantik ide yang tersusun dalam struktur teks, dengan mudah ditemukan subordinatsuperordinat oleh siswa/pembaca. Sehingga, siswa akan dengan mudah memahami teks eksposisi tersebut. Dengan demikian, kompleksitas makna dari teks eksposisi Untung Rugi Perdagangan Bebas dapat dikatakan masih sesuai dengan tingkat kesulitan atau tingkat berfikir siswa SMA/SMK.

\section{DAFTAR RUJUKAN}

Alwi, H. (2000). Tata Bahasa Baku Bahasa Indonesia. Jakarta: Balai Pustaka.

Chaer, A. (2008). Morfologi Bahasa Indonesia (Pendekatan Proses). Rineka Cipta.

Kebudayaan, K. P. dan. (2014). Bahasa Indonesia: Ekspresi Diri dan Akademik Edisi Revisi. Kementrian Pendidikan dan Kebudayaan.

Kegl, J. (1989). The Boundary Between Word Knowledge and World Knowledge. In Theoretical Issues in Natural Language Processing (pp. 28--33). Lauwrence Erlbaum.

Masnur, M. (2008). Tatabentuk Bahasa Indonesia, Kajian ke Arah Tatabahasa Deskriptif. Bumi Aksara.

Meier, P. (2007). Mind-Mapping a Tool for Elicting and Representing Knowledge Held by Diverse Informants. Social Researce Update, 52.

Pappas, C. C., Barbara, Z. K., \& Linda, S. L. (1995). An Intergrated Language 
Perspective in Elementary School: Theory into Action (2nd ed). Longman.

Priyatni, E. T. (2014). Landasan Pembelajaran Bahasa Indonesia. Bumi Aksara.

Priyatni, E. T., \& Harsiati, T. (2013). Bahasa dan Sastra Indonesia SMA/MA Kelas X. Bumi Aksara.

Samsuri. (1985). Tata Kalimat Bahasa Indonesia. PT. Sastra Hudaya.

Sinatra, R. C., Stahl-Gemake, J., \& Morgan, N. W. (1986). Using Semantic Mapping After Reading to Organize and Write Original Discourse. Jurnal of Reading, 30, 413.

Taylor, I. (1990). Psycholinguistics: Learning and Using Language. Prentice-Hall International, Inc.

Tjiptadi, B. (1984). Tata Bahasa Indonesia Cetakan III. Yudistira. 